\title{
Powerful knowledge, transformations and the need for empirical studies across school subjects
}

\author{
Niklas Gericke* - Karlstad University, Sweden \\ Brian Hudson - Karlstad University, Sweden and University of Sussex, UK \\ Christina Olin-Scheller - Karlstad University, Sweden \\ Martin Stolare - Karlstad University, Sweden
}

\begin{abstract}
In this article, we explore the concept of 'powerful knowledge' which, from a curriculum studies perspective, refers to the aspects of content knowledge towards which teaching should be oriented. We then consider how the concept of 'powerful knowledge' can be developed and operationalized as a research framework within studies in subject-specific didactics across the curriculum by relating it to the analytical concept of 'transformation'. Transformation is perceived in this case as an integrative process in which content knowledge is transformed into knowledge that is taught and learned through various transformation processes both outside and within the educational system. We argue that powerful knowledge cannot be identified based on the discipline alone, but needs to consider transformation processes and be empirically explored. A variety of theories and frameworks developed within the European research tradition of didactics are described as ways to study transformation processes related to powerful knowledge at different institutional levels as well as between different subjects and disciplines. A comparative research framework related to subject-specific education is proposed around three research questions.
\end{abstract}

Keywords: curriculum theory; powerful knowledge; school subjects; subject didactics; transformation

\section{Introduction}

From the perspective of subject didactic research, which we also refer to as 'research on subject specific education', we outline an empirical research framework that builds on the concepts of powerful knowledge and transformation across school subjects. The term 'research on subject specific education' (ROSE) was the one selected by Karlstad University to communicate and frame the interdisciplinary research area of subject didactics (see https://www.kau.se/en/rose). Powerful knowledge as an idea was coined by Michael Young (2009) to re-establish the importance of knowledge in teaching and curriculum development. Powerful knowledge is defined by Young as subject-specific, coherent, conceptual disciplinary knowledge that, when learned, will empower students to make decisions and become action-competent in a way that will influence their lives in a positive way.

In this article we develop the concept of powerful knowledge in two important ways. First, instead of only discussing powerful knowledge as an idea related to educational practices, we take a research position suggesting that it could be used as a framework in educational research that is related to subject-specific education. 
In doing so we, in line with Deng (2015), propose to align the curricular concept of powerful knowledge to the European research tradition of didactics in general and subject didactics in particular. Second, we develop the concept of powerful knowledge by refuting the dichotomization suggested by Young (2015b: 104) that curriculum ('what to teach') can be separated from pedagogy ('how to teach'). Instead, we view these two questions as interrelated in didactical research.

We suggest an expansion of the concept of powerful knowledge by using the analytical concept of transformation as a key concept in describing powerful knowledge in different disciplines, institutions and school subjects. The reason for this is that the concept of transformation takes into consideration the didactization of disciplinary knowledge, that is, how it is transformed into something that is teachable and relevant for students. Thus, the criteria for selecting the powerful knowledge to be adopted should reflect its relationship to the transformation process: what is it possible for students to learn? What is relevant for students? What is part of the curriculum? In this article transformation is defined as an integrative process in which content knowledge is changed into knowledge that is taught and learned through various processes that take place outside and within the educational system at the individual, institutional and societal levels. Here, we understand 'content knowledge' in the wider conceptual sense of not only referring to factual knowledge. Such processes of transformation are apparent in concepts related to a number of different frameworks, including 'transposition' (Chevallard, 1989, 2007), 'omstilling' (Ongstad, 2006) and 'reconstruction' (Duit et al., 2012), and are also reflected in the work of Bernstein (1971) in relation to the concept of 'recontextualization'. Our definition of transformation is purposely broad and inclusive in order to make it possible to link these various concepts to different frameworks. In this article there is no possibility of elaborating on how these frameworks relate to each other; instead we will focus on the relationship between powerful knowledge and transformation. The school subject is never a simple reduction of the discipline. Content knowledge is always transformed to fit the educational purpose of teaching. Hence, to study the concept of powerful knowledge within school subjects we need to study its processes of transformation and address the why question ('why to teach') in addition to the what and how questions.

Moreover, the concept of powerful knowledge and the transformation processes the content of powerful knowledge undergo, must be placed in a wider context, where questions addressing societal challenges are raised. In a changing society the argument is made that it is not obvious that powerful knowledge stems only from academic disciplines. For example, how does the emerging and rapidly changing media landscape affect frames for teaching and learning, and how could powerful knowledge be understood in a connected classroom? How should interdisciplinary topics such as sustainability and migration be taught and organized in school? Within a broad perspective, these questions can be described as powerful and, at the same time, as having a multi- and cross-disciplinary nature and therefore they need to be approached in this way. What is powerful knowledge in such topics then emerges as a relevant question.

We will first outline the concept of powerful knowledge, then we will elaborate on the different didactical theories and frameworks that address transformational processes in the educational system - from how knowledge is transformed from society, and between institutions, into schools, and further how the knowledge is transformed within schools and classrooms and how this influences the idea of powerful knowledge. We will relate the two key concepts to each other and then propose some important areas for empirical research as part of a research framework for future studies. 


\section{Powerful knowledge}

The notion of 'powerful knowledge' was coined by Young (2009) as a way to restore the importance of knowledge and teaching in curriculum development and research. The idea of powerful knowledge relates to aspects of conceptual knowledge to which teaching should be oriented. In discussing the question of what knowledge school students are entitled to have access to, it is argued that 'in all fields of enquiry, there is better knowledge, more reliable knowledge, knowledge nearer the truth about the world we live in and to what it is to be human' (Young, 2013: 107). Furthermore, it is argued that this knowledge is always fallible and open to challenge, and the difficulty of holding these two ideas together is highlighted. The concept of powerful knowledge is based on two key characteristics, which are expressed in the form of boundaries. First, this knowledge is specialized both in how it is produced and transmitted. This specialization is expressed in terms of the boundaries between disciplines and subjects which define their focus and objects of study. It is stressed that this is not general knowledge and that the boundaries are not fixed and unchangeable (Young, 2013). It is also emphasized that cross-disciplinary research and learning depend on discipline-based knowledge. The second characteristic is that powerful knowledge is differentiated from the experiences that pupils bring to school or older learners bring to college or university. It is also stressed that this differentiation is expressed in the conceptual boundaries between school and everyday knowledge (Young, 2013). We see this as one of the strengths of the concept of powerful knowledge - that it highlights the importance of the disciplinary knowledge in educational sciences in general and subject didactics in particular. Furthermore, this disciplinary knowledge needs to be defined, problematized and structured before it is taught. After defining how powerful knowledge is described in Young's work, we will now elaborate on the motives behind its formulation.

\section{Powerful knowledge as the third way}

Young identifies two main traditions or approaches in recent debates about knowledge in educational sciences and philosophy. These traditions are extrapolated as trajectories into possible futures. In the first tradition, denoted Future 1, knowledge is, according to Young and Muller (2010), underpinned by an 'under-socialized' epistemology and defined as fixed sets of verifiable propositions or concepts that are evaluated through standardized testing. The second tradition, denoted Future 2, arose as a response to the first, and Young and Muller (2010) claim that the epistemology of knowledge is 'over-socialized' in that the character of knowledge is reduced to 'who knows' and the identification of knowers and their practices. Both these approaches can be viewed as deficient according to Young (2015a, b).

Future 1 has been shown to be unable to motivate and engage students with the body of knowledge to be learned, and does not provide students with knowledge to tackle complex problems of society today (ibid.). The alternative approach, Future 2 , promotes the integration of school subjects and advancement of generic skills and facilitative teaching that, according to Young and Muller, are 'against their best intents [...] the main effects of Future 2-ists - those endorsing progressive pedagogy and its variants - are to render the contours of knowledge and learning invisible to the very learners that the pedagogy was designed to favour' (2010: 18-19). As a response to these deficient ways of organizing and investigating curriculum, Young and Muller suggest a social realist theory that: 'sees knowledge as involving sets of systematically related concepts and methods for their empirical exploration and the increasingly 
specialized and historically located "communities of enquirers"' (ibid.: 14). Young denotes this alternative approach as a Future 3 solution. As a result, the most important part of such a curriculum making, and thus educational research, is to identify what constitutes 'powerful knowledge' in different school subjects.

In this article we argue, in line with Young, that the return of knowledge to curriculum research is a step in the right direction. Since teaching is always 'about something', this 'something' is one of the most central issues of teaching and powerful knowledge, we believe, is a useful analytical concept for determining this 'something'. According to Young (2015a: 74) powerful knowledge can be referred to as: 'features of the particular knowledge itself that is included in curriculum and what it can do for those who have access to it'. Further: 'Knowledge is "powerful" if it predicts, if it explains, if it enables you to envisage alternatives' (ibid.). To accomplish these goals Young characterizes powerful knowledge as distinct from common sense knowledge, proposing that it is systematic, that its concepts are coherently related to each other, and, finally, that it is specialized and related to specific disciplines. In doing so he draws on the ideas from Bernstein (1999) that disciplines have specific borders of concepts, contents and skills, and that it is within these borders that new scholarly knowledge is produced. Further, Young $(2015 a, b)$ claims that it is along these borders that knowledge becomes visible and meaningful to the learner. Therefore, teaching in school should be organized into subjects that are closely related to the academic disciplines so that powerful knowledge is clearly linked to the latter. On the other hand, as seen from the quotes above, powerful knowledge is also defined as 'knowledge of the powerful', that is, it has the capacity to empower students. It is in the light of this latter perspective (and is a slightly different way of describing the concept) that we suggest in this article that the concept should be developed into a more flexible idea that can take on different meanings in different contexts or situations, by relating powerful knowledge to the concept of transformation.

In recent years the idea of powerful knowledge has generated great interest among scholars (i.e. Deng, 2015; Nordgren, 2017) and it has been suggested that it could be a powerful concept in the teaching of traditional subjects such as geography and history (Stoltman et al., 2015; Lambert, 2016; Counsell, 2011) as well as multidisciplinary topics such as interculturality (Nordgren, 2017). However, as far as we can see, there have been few empirical studies conducted into what powerful knowledge might be in different school subjects. Studies conducted to test whether powerful knowledge has positive effects on students' learning, as suggested by Young, have yet to be conducted. Accordingly, in this article we outline a research framework that focuses on how powerful knowledge is manifested at different levels of the educational system by relating powerful knowledge to the concept of didactic transformation. We argue that any successful theory that suggests changes in the educational system needs to be based on empirically based conclusions rather than only on theoretical underpinnings.

\section{The need for a holistic perspective}

As previously noted, Young makes a very clear distinction between curriculum and pedagogy, and argues that they should be regarded as separate:

it is teachers in their pedagogy, not curriculum designers, who draw on their everyday knowledge in helping them to engage with the concepts stipulated by the curriculum and to see their relevance ... the knowledge stipulated by the curriculum must be based on specialized knowledge 
developed by communities of researchers. This process can be described as curriculum recontextualization. (2015b: 97)

From our perspective, this dichotomization between curriculum and pedagogy as well as teaching and learning is not fruitful since most of the outcomes of teaching, that is, the powerful knowledge that students acquire through their teaching, depends not only on the knowledge and the teacher, but also on the learner and the milieu (Brousseau, 1997). Deng criticizes this aspect of Young's writing, arguing that: 'they fail to explain how powerful knowledge has to be unlocked and transformed to bring about the cultivation of such capacities' (2015: 775). Deng argues further that 'it needs a theory of content that concerns how knowledge is selected and transformed into curriculum content, what educational potential content has, and how such potential can be disclosed or unlocked for the development [of students' intellectual and moral powers or capacities]' (ibid.). Hence, Deng makes the case for an extension of the social realist theory of powerful knowledge to better account for (1) the process of recontextualization of the body of knowledge put to use in education, and (2) the process of teaching and learning in the classroom. Young's answer to the first quest is more one of obliviousness or, as Nordgren (2017: 4) concludes: 'Young ... becomes vague when shifting to areas where the transformation to education takes place'. Young's response to Deng's second point is the dichotomization between curriculum and pedagogy, leaving pedagogy, or the how question, out of the picture. We support Deng's propositions that a theory of powerful knowledge should be developed, and in this article make a suggestion that addresses Deng's two quests by relating powerful knowledge to the extensive European research tradition of didactics. In such a tradition the process of transforming content knowledge comes into focus.

\section{Transformation}

Powerful knowledge has mostly been described as a curriculum principle (e.g. Young, 2015a). We think that the principles behind powerful knowledge are well argued for, as discussed above. However, we suggest that these principles need to be evaluated through educational research and expanded into a teaching and learning practice, because school subjects are not mere reductions of academic disciplines (Sjøberg, 1998). In this part of the article we will explicitly address that challenge, by considering powerful knowledge in relation to the concept of transformation.

First, we need to make clear that we do not use the concept of transformation as outlined by Mezirow (1991) in his 'transformative learning theory'. This is a psychological theory about how individuals learn by changing their frames of reference to critically reflect on their assumptions and beliefs and consciously construct new ways of defining their worlds (Mezirow et al., 2000), which is more in line with a Future 2 perspective. Transformative learning has most often been used in an activist perspective in which education is seen as a means to change or transform society or the world (e.g. Mayo, 1997). Instead, we view transformation as a process of knowledge, rather than the transformation of the individual or society. However, in order to understand and explain this transformation we recognize the need to consider also the complex relations with the learner as well as the educator, as highlighted in didactical research - so there are overlaps with transformative learning theory.

Transformation in this article is defined as an integrative process in which content knowledge is transformed into knowledge that is taught and learned through various transformation processes that take place outside and within the educational system at the individual, institutional and societal levels. Hence, the concept of transformation 
in this article is understood in somewhat broader terms than is found in the framework of 'pedagogical content knowledge' (PCK) by Shulman (1986). Instead of simply considering transformation as something that is all about 'how' certain teaching content is to be represented in the classroom, as in PCK, we also link 'transformation' to the other didactical questions of why, what, for whom and when? In our view transformation involves dimensions of significance, in relation to what content in the curriculum is important and what content ought to be taught. To be able to make those choices, decisions have to be made on 'why'. In other words, what is the overarching purpose of schooling and of the subject or topic taught?

Rarely is the answer to that question found within a societal context or in the academy. Further, questions of what and why have to be connected to the aspects of teaching traditions and methods (how?), the background of students (who?) and the concrete teaching situation (when?). From a didactical viewpoint, which is the position taken here, transformation is understood as part of an integrative, didactical process (Hudson, 2002, 2016). Hence, we believe that the curriculum principle of powerful knowledge is not evident by just looking at the academic discipline. Instead, we argue that the question of what constitutes powerful knowledge is an empirical question that can be answered fully only by addressing the transformation process and these four central didactical questions.

Additionally, it is important to recognize the fact that transformation takes place at different interrelated levels inside and outside the educational system, as outlined in the Anthropological Theory of Didactics (ATD) (Chevallard, 2002). In ATD the concept of codetermination is used to analyse how knowledge is transposed both within and outside the educational system at multiple levels (Artigue and Winsløw, 2010). From an analytical perspective, it is difficult to undertake an analysis on all those levels simultaneously. Instead, we would claim that three main levels can be discerned: the societal, the institutional and the classroom levels. From a theoretical standpoint, the levels are of equal importance to learning outcomes (Bosch and Gascón, 2014), though in this article emphasis will be placed on the classroom level, which is the focus of educational research. We will discuss educational transformation processes in relation to different perspectives, mostly rooted in the German/Nordic 'Didaktik tradition' and French tradition of 'didactiques des disciplines'.

\section{Transformation on a societal level}

The contribution of ATD in didactical research is that it points out the possibility that it is factors outside the classroom, or even school, that influence the way powerful knowledge might be taught or understood. Hence, in our ambition to outline the transformation of powerful knowledge, ATD provides a framework from which to consider the societal perspective which, we argue, has been neglected in relation to the concept of powerful knowledge so far.

Education and educational research face a number of challenges due to the globalization of society. This has led education towards a Future 2 trajectory (as discussed previously) that focuses on generic skills as a way to cope with an unpredictable future and the rapid changes societies are undergoing. As Selander wrote: 'It seems obvious that our current society is in a stage of change that requires new understandings of knowledge, learning and identity formation' (2008: 267). The underlying idea of this trajectory is that the focus has turned away from knowledge to the individual learners' needs and skills. As Kress (2008: 256) points out: 'The emblematic sign of that change is the shift of emphasis in educational rhetoric from teaching to learning.' In addition, the argument is being made that the globalization process leads to the transfer of people, 
ideas and artefacts across all kinds of borders, thereby eroding the boundaries between subject disciplines. In response, teaching and curricula need to address contemporary multidisciplinary topics such as migration, interculturality, sustainability, etc. Answers to these contemporary problems are found in many subjects, not just one. Moreover, technological changes in society, such as digitalization, have changed patterns of communication and have increased accessibility, knowledge and information flow within classrooms (Olin-Scheller et al., forthcoming). Content knowledge regarded as powerful might be different in a digitized classroom compared to a non-digitized classroom. While the world is a complex and interconnected system, research, academic disciplines and education focus on individual subjects, rather than cross-disciplinary themes. These societal demands on the adaptation of education to a changing world have led to the development of curricula that focus on the development of generic competences and skills (Hargreaves, 2003).

Young criticizes this development: 'such curricula, which quite explicitly blur the curriculum/pedagogy distinction, will inevitably lack coherence and be limited as a basis for pupils to progress. The basis for choosing topics or themes would be largely arbitrary' (2015b: 103). However, Young himself recognizes that his idea of powerful knowledge and the reconceptualizing of a subject-based curriculum does not address the global transformations of society and how different subjects should relate to overlapping thematic issues (see ibid.: 103-9), and he concludes: 'The "connection" problem has no easy solution, and there is no evidence that intellectual specialization is likely to go in reverse. For schools, I suggest, it is a pedagogic not a curriculum problem' (ibid.: 104). Here we disagree with Young and suggest that by including the idea of didactical transformation, powerful knowledge can be developed as an analytical concept to underpin empirical investigations. We suggest that these multidisciplinary issues are of great societal importance, and this is exactly where empirical research should start to explore the concept of powerful knowledge. An important question to address is whether knowledge that is linked to different school subjects and relates to the same cross curricula topic (e.g. sustainability, migration) is powerful or not. The answer to that question would provide significant insight to the possible prolificacy of the theory of powerful knowledge. If powerful knowledge relating to a theme differs greatly between different school subjects, it would provide strong support for implementing a Future 3-based curriculum. Therefore, we claim that it is important to have a comparative perspective when researching powerful knowledge. It is vital to investigate relationships between the content-specific and generic features of teaching, as well as how they occur in different subjects.

Thus, we conclude that it is important to explore a relevant research framework from both a subject-specific and a cross-disciplinary perspective in relation to these societal challenges of how powerful knowledge is manifested in teaching and perceived by students and teachers.

\section{Transformation on an institutional level}

Transformation can also be understood as a process that is connected to the level of institutions. An institution can be a school, a ministry, the research community, a college, etc. Hence, here we use a definition including both informal and formal institutions that promote mechanisms of social order and behaviour (North, 1990). The interplay between different settings or levels and how knowledge is transformed between them is an important perspective in the French tradition of didactiques des disciplines. The concept of 'didactic transposition' was introduced by Chevallard $(1991,2007)$ to capture the notion that an object of learning, a certain packet of 
knowledge, tends to be transformed depending on the institutional setting. The theory of didactic transposition was a precursor to ATD theory (as previously discussed) and both point to the importance of investigating institutions beyond the classroom in didactical research. Therefore, to be able to understand the process of transformation and its outcomes, it is necessary to undertake an analysis in relation to the relevant institutional context. The process of transformation is, in that sense, embedded and mutually dependent on the institution in which it is reproduced.

Transposition is seen as a key concept in the French tradition of didactiques des disciplines (Hudson, 2016: 115). In the school context, this knowledge is not knowledge for acting and solving problems in the social contexts in which it was created and where it is used, but is transposed into knowledge to be taught and learned in the school institution. The concept of didactic transposition is based on the recognition that this 'rupture' between daily life and school changes knowledge profoundly. This, we would argue, is central to the concept of powerful knowledge. In curriculum theory in general, and powerful knowledge as a curriculum principle in particular, the content knowledge of the discipline is not distinctively separated from the school subject content (i.e. Young, 2015a, b). Instead it is often treated as the same. In our proposed research framework we see this elaboration of powerful knowledge as a central starting point for research - that is, what is regarded as powerful knowledge might be regarded differently by actors in different institutions. For example, Gericke (2009) shows in a study of biology education that the framework of Mendeilan genetics is mostly presented in school textbooks, even though this framework has only limited validity within most biological disciplines at the university level where molecular genetics is most often used. The reason for this is to be found in the didactical transposition of knowledge between institutions.

The institutional level is important since it might constrain or prompt the kind of knowledge that it is possible to teach in the classroom. A study conducted by Achiam et al. (2016) shows how objects in science teaching (consisting of palaeontological specimens of Archaeopteryx fossils) prompted scientific activities or trajectories in students' learning. Therefore, if these objects were missing or changed, the activities and subsequent learning would have turned out differently in the classroom. Therefore, to explain students' learning in the classroom, didactic transposition theory tells us that sometimes the explanations can be found at different institutional levels of the educational system, not necessarily in the classroom or in the curriculum alone.

In our framework we are using the concept of transformation instead of transposition. The reasons for this are twofold. First, transposition as a term has the semantic meaning of the movement of something from one setting to another, while transformation as a term focuses on the process of change. We think that the connotation of 'change' and 'process' is most useful to study in relations to powerful knowledge. The movement or transposition of the body of knowledge between institutions in transposition theory is more related to the explanation for this change. Second, our ambition is to encapsulate different frameworks of didactical research that also relate to the classroom level, and this would be difficult if we were to use the concept of transposition that is specifically situated within the specific framework of ATD.

The concept of didactic transposition resonates with Bernstein's (1971) conception of 'recontextualization', which refers to the selection, sequencing and pacing of content that takes into account both the coherence of the subject discipline and the limits on what can be learned by students at different stages of their development. The concept of recontextualization also recognizes the dichotomization between what can be regarded as powerful knowledge at the university level and what can 
be regarded as powerful knowledge at the school subject level. Therefore we regard the idea of recontextualization as a useful conceptual tool for the analysis of powerful knowledge in the educational system. However, the idea of recontextualization refers more to the conscious act of preparing for teaching at the classroom level (which will be discussed in the next section), while the concept of didactic transposition relates to discourse analysis, to detect unconscious 'taken for granted' restraints of what is being taught at the institutional level. Pierre Clément (2006) has developed the KVP-model which shows that the transposition between institutions is dependent not only on the knowledge $(K)$ itself, but also on values $(V)$ and social practices $(P)$ which, in the eyes of the teachers, implicitly influence the transformation processes.

School subjects and the academic disciplines have different aims. The role of school subjects is not to produce new knowledge, which could be said to be the main purpose of the academic disciplines (Gericke et al., 2014). The aim of school subjects and schools as a whole is more differentiated, incorporating educational goals relating to, for example, values (equality, democracy and so on) and skills (critical thinking, action competence). These various goals of education are captured by Biesta $(2009,2015)$ in the conceptual triad consisting of: qualification (to be able to qualify for a life at and beyond school), socialization (to be able to understand and act within social practices at and beyond school) and subjectification (to be able to understand and create meaning in relation to school practices). With reference to Biesta, the transformation of powerful knowledge at an institutional level can be viewed as filtered through the triad, that is, the content knowledge needs to be adapted by the educational goals at hand (Nordgren, 2017). Also, what is regarded as powerful knowledge might differ depending on whether the purpose of schooling is literacy (socialization) or preparation for tertiary education (qualification).

To summarize, the fact that the transformation process tends to differ according to the setting of the institution and the goals of education, means that it is of interest to investigate the very nature of powerful knowledge when these variables differ.

\section{Transformation at a classroom level}

We now turn to the classroom level - the last step in the transformation process which we would identify as the most important level. Within the German/Nordic research tradition of didactics, transformation is perceived as an integrative process. This means that the representation of teaching content in a teaching situation should not be exclusively framed as a question of how - as a methodological and/or pedagogical issue, as proposed by Young (2015b). The matter of how is only part of a bigger, more complex process of transformation. The answer to the how question is dependent on the answers to the other didactical questions: what, why, for whom and when? We understand these questions to be essential when discussing the process of transformation at the classroom level, and essential when discussing powerful knowledge. At the classroom level, the teacher, and to some extent the students, become actors in the process of defining powerful knowledge.

Historically, in research conducted within the European research tradition of Didaktik there has been an understanding that there is a dimension to the teacher's work where they are independent and have the opportunity to make didactical decisions. In the research of didactics, the teacher is not understood as implementing a given curriculum, as in the curriculum tradition. As a consequence, to arrive at a definition of powerful knowledge should not only be an issue of curriculum principles, but teachers and students should be considered to play an important part in the enactment process. The work of the teacher then becomes defined as an interpreting activity (Westbury, 
2000), but this interpretation is not carried out in a vacuum. It is obviously influenced by governance and policy, but also by the traditions of teaching that are expressed in different kinds of teaching artefacts and activities. The public view of the subject, what the content should be and how the teaching ought to be organized are also aspects of that wider context that influences the transformation process (Gericke, 2009; OlinScheller, 2006; Stolare, 2017; Eliasson and Nordgren, 2016; Bladh, 2014).

Transformation can be characterized as a situated process that permeates different parts of teaching practice (Uljens, 1997; Hopmann, 2007). An initial transformation is made in the planning phase, when the teacher draws up the lesson plans, selects the teaching content and considers how it should be represented in such a way that it will be possible for the students to grasp. A second part takes place in the actual teaching situation, when teachers and students are confronted with the representations of content. In this way, the transformation can be described as a process of continuous reconstruction that Ongstad (2006) has denoted as 'omstilling'. To view transformation in this way points to one of the foundations of the German/Nordic didactic tradition: the idea of the didactic triangle (see Figure 1).

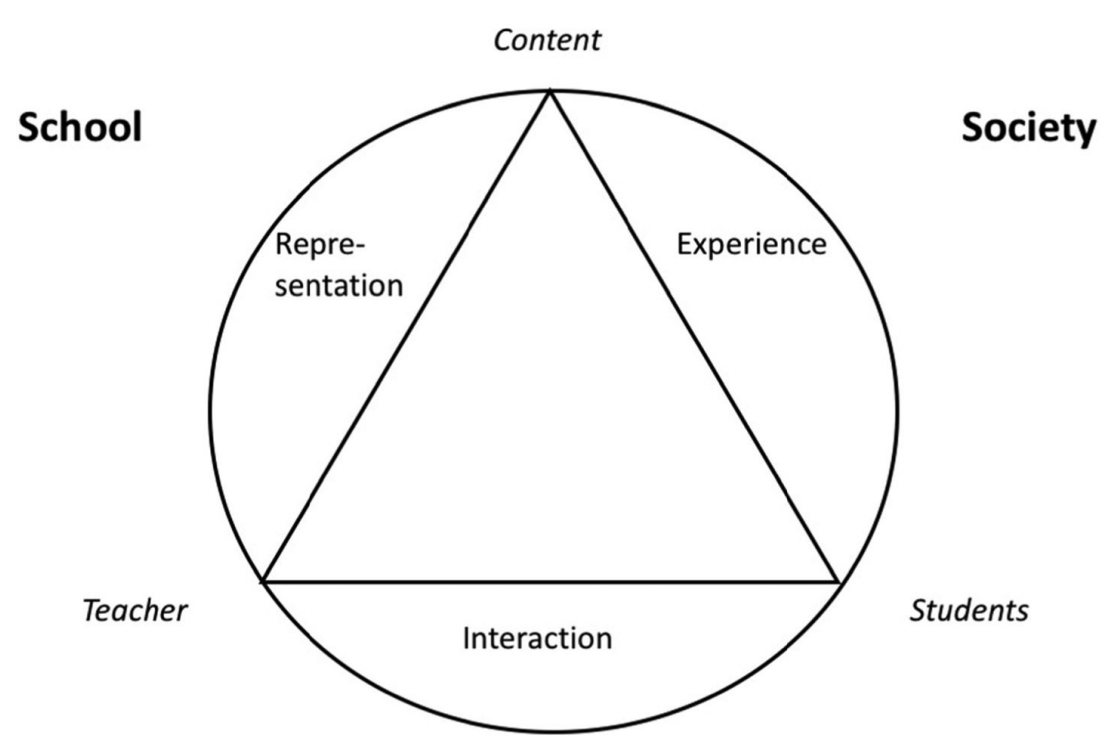

Figure 1: The didactic triangle (developed from Klafki, 1997)

The didactic triangle captures an integrative model of the various factors that shape the processes of teaching and learning (Klafki, 1997). It is integrative in the sense that it is not really considered possible to isolate a single aspect of the model. It is a relational model that stresses the interdependence of the variables. The three vertices of the triangle - the teacher, the students and the content, and especially the relationship between them - are all in play and relevant to the transformation process (Kansanen and Meri, 1999). The transformation process is influenced by students' understanding and their previous experience of the content. Here the triangle is connected to the life world of the students, and is relevant to the relationship between the teacher and the student, but also to the teacher's notion of the students' relation to the content (Klafki, 1997). Finally, the teacher's meta-understanding should be taken into consideration. If a teacher's work is viewed as an act of interpretation, the importance of the teacher's own understanding of the subject and to the content to be taught becomes crucial for its enactment in the classroom. But these relationships are not to be isolated from the 
context of the school and the society as a whole. The didactic triangle is socially and culturally embedded.

Taking the model of the didactic triangle into consideration, we claim that to be able to discern powerful knowledge at the classroom level, we need to empirically investigate teachers' and students' understandings of the content knowledge and not just take as our point of departure the disciplinary knowledge itself. In previous research inspired by the didactic tradition, it has become clear that the didactic triangle might be used as a tool in more in-depth micro-studies focusing on the act of content negotiations between the teacher and the students. This is a process in which both parties are important and where the goal is to reach a (common) understanding of the content knowledge. Another conclusion is that teachers find it difficult to introduce subject perspectives related to powerful knowledge, due to their own prior understanding of the content knowledge and strong selective subject traditions (Stolare, 2017). This means that it is essential to identify what powerful knowledge is possible to teach based on the relationships shown in the model of the didactic triangle. One way of doing that is to use the framework of didactical analysis as proposed by Klafki (1995).

The framework of didactical analysis consists of five questions. They in turn are based on earlier ideas proposed by Nohl and Weniger. The basic idea is that the value of any content knowledge can only be ascertained with reference to the individual learner and with a particular human and historical situation in mind, with its attendant past and anticipated future. The questions are:

1. What wider or general sense of reality do these contents exemplify and open up for the learner? What basic phenomenon or fundamental principle, what law, criterion, problem, method, technique or attitude can be grasped by dealing with this content as an 'example'?

2. What significance does the content in question or the experience, knowledge, ability or skill to be acquired through this topic already possess in the minds of the children in my class? What significance should it have from a pedagogical point of view?

3. What constitutes the topic's significance for the children's future?

4. How is the content structured? (How has the content been placed into a specifically pedagogical perspective by questions 1, 2 and 3?)

5. What are the special cases, phenomena, situations, experiments, persons, elements of aesthetic experience, and so forth, in terms of which the structure of the content in question can become interesting, stimulating, approachable, conceivable, or vivid for children of the stage of development of this class? (Klafki, 2000: 152-55)

Through this framework, classroom practice can be analysed. What becomes clear is that behind these questions lies a strategy to address the issue of significance. What is to be taught (which we would denote powerful knowledge) should be significant from the perspective of the children's future (question 3). Significance points towards the importance of values, because these can only be assessed based on the goals of education. The question to address is: what knowledge has the capacity to empower students? This can be only be answered in the light of the goals of education, be they qualification, socialization or subjectification (Biesta, 2009, 2015).

In his later work Klafki discussed Epochaltypische Schlüsselproblemen (key problems). In short, education should deal with the important, and sometimes controversial, societal issues of today (Klafki, 1997). Here Klafki clearly connects didactical 
practice to surrounding society, which we discussed in a previous section. Hence, the different levels of the educational system, as outlined in this article, should not be viewed as independent from one another. Instead, we view them as interconnected and mutually interdependent through the various transformation processes we have outlined. That is why it is crucial to expand the concept of powerful knowledge to also encompass the various transformation processes and their importance for teaching and learning.

With reference to Klaffki's (1995) framework of didactic analysis, Barrett et al. (2018) note that the process of reducing the knowledge-to-be-taught into digestible learning bites helps the teacher to show how the reduction can be 'unlocked' to expand the range of its generalizability and induct the learners into 'unlocking' it themselves, a process called 'double unlocking' by Krüger (2008). They observe how this adds an extra dimension to the Bernsteinian (2000) concept of 'recontextualization', that is, the curriculum is not just to be translated but rather it is also to be compressed and then decompressed. It is this dimension that Deng (2015) thinks social realists such Young have so far missed when developing the concept of powerful knowledge. At the same time Barrett et al. note that Bernstein shares the Didaktik view of the unity of the curriculum and pedagogy, and that he acknowledges Klafki with thanks on this point in the notes to his chapter (Bernstein, 1971: 175). Furthermore they observe, quite rightly in our view, that this unity is a point that seems to have been lost in contemporary curriculum studies, which we would refer to as transformations.

In parallel with developments in the German/Nordic tradition, the French research tradition has developed frameworks to understand and describe the transformation processes at the classroom level. The need for integrative thinking, in contrast to reductionism, is also reflected in the Francophone tradition as elaborated by Sensevy (2011). He argues that the first theoretical principle of French didactics is that in order to understand a didactic activity (that is, an activity where someone teaches and someone learns) you need to understand the didactic system as comprising three subsystems: knowledge, the teacher and the student. The Joint Action Theory of Didactics (JATD) operationalizes this holistic view into a systematically organized set of concepts and analytic tools that can be used in relation to classroom observation studies. Hence, these tools were already originally developed from a research rather than a curriculum perspective (Sensevy, 2011). JATD elaborates the last step of the didactic transposition, that is, the transformation process in the classroom. In comparison to Klafki's frameworks, the tools and concepts of JATD are of a more analytical nature. Within JATD the concept of the didactic contract is used to describe the system of habits, which is largely implicit, between the teacher and the students in relation to the knowledge in question. On the basis of the habits established in the didactic situation, each participant (the teacher or the student(s)) attributes some expectations to the other(s). In order to learn, students have to deal with a situation involving a problem that previous knowledge does not allow them to solve. In JATD this situation is referred to as a milieu (Brousseau, 1997) which describes a system of material and symbolic objects that correspond to the new knowledge the students are to acquire. According to this description, the older pieces of knowledge enable the teacher and the students to act jointly, whereas the new knowledge involves a kind of resistance to the students' action (Gruson et al., 2012: 65). Here we see a possible connection to powerful knowledge. JATD also aims at identifying the transformed knowledge in the classroom. However, in this theory, powerful knowledge is acted upon and transformed by both the teachers and the students, which is our viewpoint in this article. 
In JATD the didactic transactions between the teacher and the students are described as a game of a particular kind - a didactic game in which some specific pieces of knowledge are involved. The didactic game is seen as collaborative, one that takes place within a joint action (Gruson et al., 2012: 65). One exemplar of the application of JATD to a particular episode of classroom interaction can be found in Hudson (2015). The findings from this study highlight the ways in which the students actively engaged in the milieu and the ways in which the teachers developed the 'didactic game' by extending the 'epistemic games' through the use of an open-ended, topic-based approach combined with effective teacher questioning. He also highlights the ways in which the discursive elements of 'learning games' as part of these lessons proved to be a very effective means through which to support the students to engage in the milieu and to develop mathematical thinking. A second exemplar is a case of teachinglearning in a non-school context, which is based on education for toddlers through aquatic motor-awakening activities, commonly referred to as 'swimming babies'. This article presents a case study of how a young girl learned to 'blow bubbles' under water (Loquet, 2011). The reason we address JATD is that we believe it to be a useful tool for those interested in investigating the enactment of powerful knowledge in the classroom.

What we have tried to show from these frameworks of didactical research at the classroom level from the Nordic/German as well as French traditions is that it is almost impossible to make a clear dichotomization between curriculum and pedagogy because teaching and learning is mutually interdependent according to these didactical theories. It is not possible to establish powerful knowledge without considering these transformation processes. In the next section, we will synthesize and discuss how the concepts of transformation and powerful knowledge could relate to each other, and how we could explore this relationship.

\section{Powerful knowledge and transformation: A synthesis into an integrative research framework}

We find that the concept of powerful knowledge adds merit to subject didactic research, as discussed above, by pointing out the importance of disciplinary knowledge, and how this disciplinary knowledge needs to be defined, problematized and structured before teaching takes place. However, from our perspective, the dichotomization between curriculum and pedagogy as well as teaching and learning is not fruitful. We see the need to expand the theory of powerful knowledge and relate it to the research traditions of didactics in general and the concept of transformation in particular. Based on this article we suggest that:

- Powerful knowledge should be considered in relation to transformation as a flexible concept that can be described and identified at the levels of society, institutions and classroom.

- As a consequence, what constitutes powerful knowledge might differ between these levels.

- These possible differences are dependent on the transformation processes occurring between the levels.

- Tools for investigating the transformation processes, which lead to specific powerful knowledge, can be found within the European research traditions of didactics. 
Accordingly, powerful knowledge cannot be defined solely by the discipline, but needs to be adopted by considering the didactization (Ongstad, 2006) of conceptual knowledge through the transformation process. By didactization we mean the process by which a school subject is adopted for teaching due to societal and contextual influences. If there are obstacles in the transformation process (for example, students might lack the necessary pre-knowledge to understand the concept or they might have negative attitudes, depending on the social context) it would not be meaningful to teach it. Therefore, we need to consider transformation while identifying powerful knowledge.

Further, not all school subjects are linked to a discipline(s) in the same way. Some school subjects are connected to a single discipline (e.g. history, mathematics) but other school subjects have connections to several different disciplines (e.g. science, mother tongue language, civics). Those school subjects might be described as interdisciplinary by their very nature. Keeping these facts in mind we think it is necessary to investigate and compare transformation processes and powerful knowledge across many school subjects and disciplines. By focusing on powerful knowledge and the corresponding transformation processes through a comparative approach, it should be possible to illuminate the didactical commonalities and differences between different subjects and how they influence teaching and learning. In contemporary didactical research, the focus is shifting more towards what we in this article denote as 'research on subject-specific education' or what in a European tradition is called 'ämnesdidaktik' (Swedish), 'fachdidaktik' (German) or 'didactiques des disciplines' (French). The starting point in subject-specific education is that the different knowledge traditions and epistemologies of different subjects are diverse, and these premises are decisive in teaching and learning, and will inevitably influence both the way content is selected (the what and why questions) and the way it is taught (the how question). In that sense, it conforms to the ideas of transformation and powerful knowledge as formulated in this article. Thus, by drawing on both subjectspecific and cross-disciplinary perspectives, we argue for a research framework to investigate processes of how powerful knowledge is manifested in teaching and perceived by students and teachers in different subjects and topics.

Our ambition in this article has been to point to the importance of linking the traditions of didactics, here especially German/Nordic and French, to the curriculum perspective of powerful knowledge. This has been done by applying an inclusive definition of the concept of transformation. The idea is that through the holistic integrative didactic approach, emphasis is placed on the complexity of the transformation of powerful knowledge in relation to the school subjects. But it is also suggested that the concepts present in the didactic traditions, some of which we discussed here - the didactic triangle, didactic questions, transposition, (epistemic-, didactic-, learning-) games - could work as frameworks to better grasp and unfold the process of transformation. The next step will be to establish a more elaborated framework. This can be done only through empirical studies, preferably of a comparative nature, as we argued above. In doing so we would, based on this article, suggest that research should consider these three overarching research questions:

1. How can the nature of powerful knowledge in different school subjects be characterized?

2. How can the transformation processes related to powerful knowledge be described?

3. What are the barriers against, and the conditions for, transformation of powerful knowledge in different subjects? 
These proposals we believe will ensure that there is a good possibility that we will be able to develop the theoretical, as well as empirical, underpinnings of the concept of powerful knowledge and, at the same time, start the merging process of curriculum research with didactical research by combining the most advantageous aspects from both traditions.

\section{Notes on the contributors}

Niklas Gericke is Professor in Science Education, Director of the SMEER (Science, Mathematics and Engineering Education Research) research centre at Karlstad University in Sweden and guest professor at NTNU in Trondheim, Norway. His main research interests are biology education and sustainability education. Much of his work relates to how disciplinary knowledge is transformed into school knowledge and what impact these transformations have on teachers' work and students' understanding.

Brian Hudson is Professor of Education and former Head of the School of Education and Social Work at the University of Sussex, guest professor at Karlstad University and honorary professor at the University of Dundee. He is a Fellow of the Institute of Mathematics and its Applications, an honorary member of EERA Network 27 Didactics - Learning and Teaching and was awarded a National Teaching Fellowship in 2004. His main research interests are in mathematics education, ICT and learning and comparative curriculum studies.

Christina Olin-Scheller is Professor in Educational Work, Director of the CSL (Centre of Language and Literature in Education) research centre and the ROSE (Research on Subject-Specific Education) research group at Karlstad University. Her main research interests are young people's reading and writing in a new media landscape as well as questions dealing with reading instruction and reading development. She coordinates the Swedish National Literacy Network and participates in the Nordic QUINT (Quality in Nordic Teaching) research centre.

Martin Stolare is Associate Professor in History at Karlstad University. In his research, he focuses on primary school and teaching and learning in history and social studies. With a background as a historian, a particular interest of his is the interplay between history as a discipline and as a school subject. In the last decade he has run several practice-based research projects with in-service teachers.

\section{References}

Achiam, M., Simony, L. and Lindow, B.E.K. (2016) 'Objects prompt authentic scientific activities among learners in a museum programme'. International Journal of Science Education, 38 (6), 1012-35.

Artigue, M. and Winsløw, C. (2010) 'International comparative studies on mathematics education: A viewpoint from the anthropological theory of didactics'. Recherches en Didactique des Mathématiques, 30 (1), 47-82.

Barrett, B., Hoadley, U. and Morgan, J. (eds) (2018) Knowledge, Curriculum and Equity: Social realist perspectives. London: Routledge.

Bernstein, B. (1971) Class, Codes and Control: Volume 1: Theoretical studies towards a sociology of language. London: Routledge and Kegan Paul.

Bernstein, B. (1999) 'Vertical and horizontal discourse: An essay'. British Journal of Sociology of Education, 20 (2), 157-73.

Bernstein, B. (2000) Pedagogy, Symbolic Control and Identity: Theory, research, critique. Rev. ed. Lanham, MD: Rowman and Littlefield. 
Biesta, G. (2009) 'Good education in an age of measurement: On the need to reconnect with the question of purpose in education'. Educational Assessment, Evaluation and Accountability, $21(1), 33-46$.

Biesta, G. (2015) 'What is education for? On good education, teacher judgement, and educational professionalism'. European Journal of Education, 50 (1), 75-87.

Bladh, G. (2014) 'Geografilärare och geografiundervisning i den svenska grundskolan: Några delresultat av en enkätstudie'. Geografiska Notiser, 72 (4), 158-68.

Bosch, M. and Gascón, J. (2014) 'Introduction to the anthropological theory of the didactic (ATD)'. In Bikner-Ahsbahs, A. and Prediger, S. (eds) Networking of Theories as a Research Practice in Mathematics Education (Advances in Mathematics Education). Cham: Springer, 67-83.

Brousseau, G. (1997) Theory of Didactical Situations in Mathematics: Didactique des mathématiques, 1970-1990. Dordrecht: Kluwer Academic.

Chevallard, Y. (1989) 'On didactic transposition theory: Some introductory notes'. Paper presented at the International symposium on selected domains of research and development in mathematics education, proceedings, 51-62, Bratislava, Slovakia.

Chevallard, Y. (1991) La transposition didactique: Du savoir savant au savoir enseigné. 2nd ed. Grenoble: La Pensée Sauvage.

Chevallard, Y. (2002) 'Organiser l'étude 3: Écologie et régulation'. In Dorier, J.-L., Artaud, M., Artigue, M., Berthelot, R. and Floris, R. (eds) Actes de la 11e école de didactique des mathématiques. Grenoble: La Pensée Sauvage, 41-56.

Chevallard, Y. (2007) 'Readjusting didactics to a changing epistemology'. European Educational Research Journal, 6 (2), 131-4.

Clément, P. (2006) 'Didactic transposition and the KVP model: Conceptions as interactions between scientific knowledge, values and social practices'. Paper in the Proceedings of the ESERA Summer School, Braga, Portugal, 9-18.

Counsell, C. (2011) 'Disciplinary knowledge for all, the secondary history curriculum and history teachers' achievement'. Curriculum Journal, 22 (2), 201-25.

Deng, Z. (2015) 'Content, Joseph Schwab and German Didaktik'. Journal of Curriculum Studies, 47 (6), 773-86.

Duit, R., Gropengießer, H., Kattmann, U., Komorek, M. and Parchmann, I. (2012) 'The model of educational reconstruction - a framework for improving teaching and learning science'. In Jorde, D. and Dillon, J. (eds) Science Education Research and Practice in Europe: Retrospective and prospective. Rotterdam: Sense Publishers, 13-37.

Eliasson, P. and Nordgren, K. (2016) 'Vilka är förutsättningarna i svensk grundskola för en interkulturell historieundervisning?'. Nordidactica: Journal of Humanities and Social Science Education, 2, 47-68.

Gericke, N. (2009) Science versus School-Science: Multiple models in genetics - The depiction of gene function in upper secondary textbooks and its influence on students' understanding (Karlstad University Studies 2008: 47). Doctoral dissertation. Karlstad: Karlstads universitet.

Gericke, N.M., Hagberg, M., Carvalho dos Santos, V., Joaquim, L.M. and El-Hani, C.N. (2014) 'Conceptual variation or incoherence? Textbook discourse on genes in six countries'. Science and Education, 23 (2), 381-416.

Gruson, B., Loquet, M. and Pilet, G. (2012) 'Analyzing semiosis process in primary classrooms: Case studies in second language and gymnastics'. Paper presented at the International Colloquium on Forms of Education and Emancipation Processes, Centre for Research in Education and Didactics (CREAD), Rennes.

Hargreaves, A. (2003) Teaching in the Knowledge Society: Education in the age of insecurity. New York: Teachers College Press.

Hopmann, S. (2007) 'Restrained teaching: The common core of Didaktik'. European Education Research Journal, 6 (2), 109-24.

Hudson, B. (2002) 'Holding complexity and searching for meaning: Teaching as reflective practice'. Journal of Curriculum Studies, 34 (1), 43-57.

Hudson, B. (2015) 'Butterflies and moths in the Amazon: Developing mathematical thinking through the rainforest'. Éducation et Didactique, 9 (2), 119-33.

Hudson, B. (2016) 'Didactics'. In Wyse, D., Hayward, L. and Pandya, J. (eds) The SAGE Handbook of Curriculum, Pedagogy and Assessment. London: SAGE Publications, 107-24.

Kansanen, P. and Meri, M. (1999) 'The didactic relation in the teaching-studying-learning process'. In Hudson, B., Buchberger, F., Kansanen, P. and Seel, H. (eds) Didaktik/Fachdidaktik as Science(-s) of the Teaching Profession? Umeå : Thematic Network on Teacher Education in Europe, 107-16.

Klafki, W. (1995) 'Didactic analysis as the core of preparation for instruction (Didaktische Analyse als Kern der Unterrichtsvorbereitung)'. Journal of Curriculum Studies, 27 (1), 13-30. 
Klafki, W. (1997) 'Kritisk-konstruktiv didaktik'. In Uljens, M. (ed.) Didaktik: Teori, reflektion och praktik. Lund: Studentlitteratur, 215-28.

Klafki, W. (2000) 'Didaktik analysis and the core of preparation of instruction'. In Westbury, I., Hopmann, S. and Riquarts, K. (eds) (2000) Teaching as a Reflective Practice. The German Didaktik tradition. London: Routledge, 139-60.

Kress, G. (2008) 'Meaning and learning in a world of instability and multiplicity'. Studies in Philosophy and Education, 27 (4), 253-66.

Krüger, R.A. (2008) 'The significance of the concepts "elemental" and "fundamental" in didactic theory and practice'. Trans. Yonge, G.D. Journal of Curriculum Studies, 40 (2), 215-50.

Lambert, D. (2016) 'Geography'. In Wyse, D., Hayward, L. and Pandya, J. (eds) The SAGE Handbook of Curriculum, Pedagogy and Assessment. London: SAGE Publications, 391-407.

Loquet, M. (2011) 'Swimming babies - on joint didactic action in physical and sports activities: A case study in a non-schooling institution'. In Hudson, B. and Meyer, M.A. (eds) Beyond Fragmentation: Didactics, learning and teaching in Europe. Opladen: Barbara Budrich, 287-301.

Mayo, M. (1997) Imagining Tomorrow: Adult education for transformation. Leicester: National Institute of Adult Continuing Education.

Mezirow, J. (1991) Transformative Dimensions of Adult Learning. San Francisco: Jossey-Bass.

Mezirow, J. and Associates (2000) Learning as Transformation: Critical perspectives on a theory in progress. San Francisco: Jossey-Bass.

Nordgren, K. (2017) 'Powerful knowledge, intercultural learning and history education'. Journal of Curriculum Studies, 49 (5), 663-82.

North, D.C. (1990) Institutions, Institutional Change and Economic Performance. Cambridge: Cambridge University Press.

Olin-Scheller, C. (2006) Mellan Dante och Big Brother: En studie om gymnasieelevers textvärldar. (Karlstad University Studies 67). Karlstad: Karlstad University Press.

Olin-Scheller, C., Sahlström, F. and Tanner, M. (forthcoming) 'Smartphones in classrooms: Reading, writing and talking in rapidly changing educational spaces: Introduction'. Learning, Culture and Social Interaction.

Ongstad, S. (ed.) (2006) Fag og didaktikk i læerutdanning: Kunnskap i grenseland. Oslo: Universitetsforlaget.

Selander, S. (2008) 'Designs of learning and the formation and transformation of knowledge in an era of globalization'. Studies in Philosophy and Education, 27 (4), 267-81.

Sensevy, G. (2011) 'Overcoming fragmentation: Towards a joint action theory in didactics'. In Hudson, B. and Meyer, M.A. (eds) Beyond Fragmentation: Didactics, learning and teaching in Europe. Opladen: Barbara Budrich, 60-76.

Shulman, L.S. (1986) 'Those who understand: Knowledge growth in teaching'. Educational Researcher, 15 (2), 4-14.

Sjøberg, S. (1998) Naturfag som allmenndannelse: En kritisk fagdidaktikk. Oslo: Gyldendal.

Stolare, M. (2017) 'Did the Vikings really have helmets with horns? Sources and narrative content in Swedish upper primary school history teaching'. Education 3-13: International Journal of Primary, Elementary and Early Years Education, 45 (1), 36-50.

Stoltman, J., Lidstone, J. and Kidman, G. (2015) 'Powerful knowledge in geography: IRGEE editors interview Professor David Lambert, London Institute of Education, October 2014'. International Research in Geographical and Environmental Education, 24 (1), 1-5.

Uljens, M. (1997) 'Grunddrag till en reflektiv skoldidaktisk teori'. In Uljens, M. (ed.) Didaktik: Teori, reflektion och praktik. Lund: Studentlitteratur, 166-97.

Westbury, I. (2000) 'Teaching as a reflective practice: What might Didaktik teach curriculum?'. In Westbury, I., Hopmann, S. and Riquarts, K. (eds) Teaching as a Reflective Practice: The German Didaktik tradition. Mahwah, NJ: Lawrence Erlbaum Associates, 15-40.

Young, M. (2009) 'Education, globalisation and the "voice of knowledge"'. Journal of Education and Work, 22 (3), 193-204.

Young, M. (2013) 'Overcoming the crisis in curriculum theory: A knowledge-based approach'. Journal of Curriculum Studies, 45 (2), 101-18.

Young, M. (2015a) 'Powerful knowledge as a curriculum principle'. In Young, M., Lambert, D., Roberts, C. and Roberts, M. (eds) Knowledge and the Future School: Curriculum and social justice. 2nd ed. London: Bloomsbury Academic, 65-88.

Young, M. (2015b) 'The progressive case for a subject-based curriculum'. In Young, M., Lambert, D., Roberts, C. and Roberts, M. (eds) Knowledge and the Future School: Curriculum and social justice. 2nd ed. London: Bloomsbury Academic, 89-109.

Young, M. and Muller, J. (2010) 'Three educational scenarios for the future: Lessons from the sociology of knowledge'. European Journal of Education, 45 (1), 11-27. 